Research Article

\title{
Effect of Family Support Towards Elderly Hemodialysis Patients' Anxiety Level
}

\author{
Andri Nugraha ${ }^{1}$, Ghina Utari Rahmah ${ }^{1}$, Purbayanti Budhiaji ${ }^{2}$ \\ 1 STIKes Karsa Husada Garut \\ ${ }^{2}$ General Hospital of Dr. Slamet Garut
}

Article history:

Submission December 2019

Revised March 2020

Accepted March 2020

*Corresponding author:

E-mail:

andrinugraha@outlook.com

\begin{abstract}
One of many ways to decrease the morbidity and mortality rates on elderly hemodialysis patients is by decreasing their anxiety level on therapy sessions by family support. This research's purpose is to find out the effect of family support on the elderly hemodialysis patients' anxiety levels. The participants were 50 elderly hemodialysis patients. This research used a crosssectional design. The questionnaire was adopted from House's theory, the anxiety level was measured with Self-Rating Anxiety Scale (SAS), and ordinal regression was used for statistical analysis. The results showed that there was a significant correlation between family support and elderly hemodialysis patients' anxiety level $(\mathrm{P}=0.026)$. The absence of family support affected the anxiety level from mild to moderate range. Patients without family support had 4,4 times higher chance to get mild to moderate anxiety than those with family support. Patients with chronic kidney failure who are under hemodialysis therapy treatment and having family support can increase their quality of life.
\end{abstract}

Keywords: Hemodialysis, anxiety, family support, elderly

\section{Introduction}

When someone got older, chronic diseases can affect not only his ability to live independently but also his quality of life. One of the common chronic diseases is kidney failure [1]. Chronic renal failure (CRF) is the continuous and irreversible decrease of kidney tissue function that the kidney cannot sustain body metabolism, fluid, and electrolyte balance for at least three months. [2], [3]. A patient can be categorized as CRF and should be under a hemodialysis therapy if the creatinine level test and GFR test show $<15 \mathrm{ml} / \mathrm{min} / 1,73 \mathrm{~m}^{2}$. This phase is called end-stage renal disease (ESRD) [4]-[6].

Hemodialysis is a process of metabolic waste in blood disposal, such as urea, creatinine, and water, through a machine that has a semipermeable membrane that functions as a blood separator and dialysate fluid in artificial kidneys, and diffusion, osmosis, and ultrafiltration [4]. The purpose of hemodialysis is to eliminate the accumulation of toxins from the oxidative processes that could decrease body endurance and damage the normal body cell function [6].

Based on the Riskesdas results in 2013, $\mathrm{CRF}$ in Indonesia had an increase in prevalence along with the increasing age. A sharp increase occurred in the 44-70 years-old age group compared to 25-34 years-old age group. The prevalence was also higher in men $(0.3 \%)$ than women $(0.2 \%)$ [7].

The complications that could occur during hemodialysis therapy are headaches, muscle cramps, nausea and vomiting, fever, hypotension, hypertension, disequilibrium syndrome, hemodialysis-related infections, and thrombocytopenia; those could trigger patients' anxiety [8]. Besides, the long-term effects of hemo- 
dialysis can make the patients feel anxious because of losing their job or economy, decrease in mobility, physical and cognitive strength, loss of sexual function, and the fear of dying [9].

Anxiety is a feeling of discomfort or concern about the psychiatric symptoms but it is often overlooked on patients with ESRD who undergo hemodialysis [10]. Anxiety is a nonspecific symptom, characterized by feelings and emotions in relation to uncertainty and fear [11]. Anxiety is a psychological problem and becomes the leading cause of fatigue on patients that leads to the decrease of adherence to treatment, such as the duration of the dialysis session, and adherence to an inadequate nutritional diet characterized by a weight loss [12]-[15].

Family support plays an essential role in the well-being of patients. Family support is the assistance of other family members who will provide physical and psychological comfort, such as attention, appreciation, or helping the patient to accept their conditions [15][17].

Elderly patients with chronic kidney failure under hemodialysis therapy and excellent support from their family will have their quality of life improved [12], [16]. Because of the higher number of elderly patients who do hemodialysis and the impact caused by the restrictions and changes in lifestyle, they need support from all parties, particularly from their family as a support system for patients [14]-[16].

\section{Material and Methods}

This study used a cross-sectional study design. Ethical permits were submitted to the research unit of the Institute of health science Karsa Husada, Garut until the writers obtained research permission and publication information. The subject was 50 people, selected by a purposive sampling technique. The subjects who met the requirements for this study were elderly patients who were undergoing hemodialysis therapy at RSUD Dr. Slamet Garut, the patient's awareness was compos mentis, and able to communicate, read, and write well.

Data was collected using a questionnaire about the characteristics of respondents and family support, which was adopted from previous studies [18] according to House theory [19]. The patient's anxiety measurement was adopted from the Zung Self-Rating Anxiety Scale (SAS) [20], [21] that was declared valid and reliable.

Univariate analysis was used to describe the distribution frequency and the percentage of respondents' characteristics. The bivariate analysis was Fisher's exact test. Ordinal regression statistical test was used to estimate the effectiveness of family support to the anxiety level of patients undergoing advanced hemodialysis therapy.

\section{Results and Discussion}

Table 1 shows that the majority of the sample in this study were elderly (74\%), male (62\%), and elementary/ junior high school (32\%). Table 1 also shows that the majority of respondents are self-employed (62\%) and have been doing hemodialysis for $<2$ years (58\%).

In Table 2., Fisher's exact test results show that there is a significant relationship between the family support and anxiety level with a $p$ value of $0.026(\mathrm{P}<0.05)$.

The ordinal regression test results in Table 3 show that the absence of family support affects the level of mild-moderate anxiety and the chance of an elderly hemodialysis patient feeling mild-moderate anxiety is 4,441 times higher if the patient does not get any family support compared to patients with family support.

Table 1. The Distribution of Hemodialysis Patients Based on Respondents Age, Gender, Education, Occupation, and Duration of Hemodialysis

Age

Variables $\quad$ Frequency (f) Percentage (\%)

Pre-Elderly (45-59 years-old) 
Sex

male

Female

Education

Elementary

Junior high school

Senior high school

University

Occupation

Housewife

Self-employment

Civil servant/ private employees

Hemodialysis duration

$$
\text { - } \quad \leq 24 \text { month }
$$

Table 2. The Correlation between Family Support and Elderly Hemodialysis Patients' Anxiety Level

\begin{tabular}{lllll}
\hline Family support & Anxiety level & & & P-Value \\
& Normal (N) & Mild- Moderate (N) & Severe (N) & \\
\hline Supportive families & 8 & 12 & 15 & $0,026^{*}$ \\
Unsupportive families & 3 & 8 & 4 & \\
\hline
\end{tabular}

*Significant when $\mathrm{P}<0,05$

Table 3. The effects of Family Support on Elderly Hemodialysis Patients' Anxiety Level

\begin{tabular}{lllll}
\hline Variables & Category & Coef. (E) & Exp (E) & P=Value \\
\hline Family support & Unsupportive family & 1,491 & 4,441 & $0,09^{*}$ \\
Anxiety level & Normal & 0,691 & 1,995 & $0,88^{*}$ \\
& Mild - moderate & 1,288 & 3,625 & $0,04^{*}$ \\
\hline
\end{tabular}

*Significant when $\mathrm{P}<0,05$

This study shows that there is a relationship between family support and the level of anxiety of elderly hemodialysis patients. This is consistent with studies that show that elderly hemodialysis patients can experience anxiety because of the presence of stressors, such as limited economic conditions, changes in social relationships with the community and marital relations, limited time for rest and recreation, hospitalization, fear of disability or death, the uncertainty of recovery from illness, and fatigue [22], [23]. The results of this study also per the statement that there is a significant relationship between the level of social support, family support, and the quality of life on elderly hemodialysis patients with chronic kidney failure [14], [24]. Other studies stated that to reduce anxiety in adult and elderly pa tients who undergo hemodialysis, social support is needed, especially family support. [14].

Effective and efficient family support is the key to improve the well-being of patients undergoing hemodialysis therapy, especially in the elderly [25], [26]. Family support for the elderly in form of giving emotions, expressed in behaviors such as listening and paying attention that makes the person feel noticed, and social support in daily life assistance, such as material and financial support or in daily activities, can improve the patient's quality of life [1], [14], [27].

The effect of the absence of family support gives elderly patients mild to moderate anxiety. This is following the study that states that older people have a higher risk of anxiety and depression compared to other ages who are 
undergoing hemodialysis therapy [28] especially in patients who do not get any family support [29], [30]. This happens because most older people, who undergo hemodialysis therapy, experience a decrease in interpersonal relationships, socio-economic and cognitive levels, and the adherence to the therapy [30], [31], while having an increased risk of accidental falls [32]. Falling in elderly patients can cause many complications, like an injury to extremities, disability and loss of independence, poor quality of life, increased cost for treatment, and increased patient morbidity and mortality. The absence of family support and social support results in an increased risk of death and decreased adherence to treatment, especially the duration of the dialysis session and weight gain [14], [33].

\section{Conclusion}

Chronic kidney failure patients with hemodialysis therapy treatment and family support can increase their quality of life. There was a significant correlation between family support and elderly hemodialysis patients' anxiety level and the absence of it affected the anxiety level from mild to moderate range. It is expected that the hospital can improve and maintain in providing counseling about family support. For further research, it is expected that explore the experiences of families caring for older people with hemodialysis.

\section{Acknowledgment}

The authors thank STIKes Karsa Husada Garut and the general Hospital of Dr. Slamet Garut for supporting this research.

\section{References}

1. Kaur K, Kaur H, Venkateashan M (2015) Factors determining family support and quality of life of elderly population. Int. J. Med. Sci. Public Heal. 4 (8): 1049-1054.

2. Fraser SD, Blakeman T (2016) Chronic kidney disease: identification and management in primary care. Pragmatic Obs. Res. 7: 21-32.

3. Leung DKC (2003) Psychosocial aspects in renal patients. Perit. Dial. Int. 23 (2): S90-S94

4. Vadakedath S, Kandi V (2017) Dialysis: A Review of the Mechanisms Underlying Complications in the Management of Chronic Renal Failure. Cureus 9 (8): e1603-e1603.
5. Patel SS, Kimmel PL, Singh A (2002) New Clinical Practice Guidelines for Chronic Kidney Disease: A Framework for K/DOQI. Semin. Nephrol. 22 (6): 449-458.

6. Inker LA et al. (2014) KDOQI US commentary on the 2012 KDIGO clinical practice guideline for the evaluation and management of CKD. Am. J. Kidney Dis. 63 (5): 713-735.

7. Kementrian Kesehatan RI (2017) InfoDATIN, 1st ed. Jakarta: Kementrian Kesehatan RI.

8. Anusha M, Gari H, Rathinavelu M, Gari AH (2017) Acute complications associated with haemodialysis in a CKD cohort population. Indian Journal of Pharmacy Practice 10 (2): 1-10. doi: 10.5530/ijopp.10.2.18.

9. Turkistani I et al. (2014) The prevalence of anxiety and depression among end-stage renal disease patients on hemodialysis in Saudi Arabia. Ren. Fail. 36 (10): 15101515 .

10. Cohen SD, Cukor D, Kimmel PL (2016) Anxiety in patients treated with hemodialysis. Clin. J. Am. Soc. Nephrol. 11 (12): 2250 - 2255.

11. Locke AMYB, Kirst N, Shultz CG, Medical M, Arbor A (2015) Diagnosis and management of generalized anxiety disorder and panic disorder in adults. Am. Fam. Physician 9 (1), 618-624.

12. Kim K, Kang GW, Woo J (2018) The quality of life of hemodialysis patients is affected not only by medical but also psychosocial factors: a canonical correlation study. J. Korean Med. Sci. 33 (14): e111-e111.

13. Rezaei Z, Jalali A, Jalali R, Khaledi-Paveh B (2018) Psychological problems as the major cause of fatigue in clients undergoing hemodialysis: A qualitative study. Int. J. Nurs. Sci. 5 (3): 262-267.

14. Da Silva SM, Braido NF, Ottaviani AC, Gesualdo GD, Zazzetta MS, Orlandi F -de S (2016) Social support of adults and elderly with chronic kidney disease on dialysis. Rev. Lat. Am. Enfermagem 24: e2752-e2752.

15. Maryam RS, Resnayati Y, Riasmini NM, Mambang Sari CW (2018) Effect of family support intervention towards quality of life with Elderly's hypertension in community. Padjadjaran Nurs. J. 6 (3): 1-10.

16. Chandra L, Pandu W, Putranto W, Fanani M (2014) Association between hemodialysis adequacy, family support, and quality of life in chronic renal failure patients. Indones. J. Med. 2 (1): 63-72.

17. Lilympaki I, Makri A, Vlantousi K, Koutelekos I, Babatsikou F, Polikandrioti M (2016) Effect of perceived social support on the levels of anxiety and depression of hemodialysis patients. Mater. Sociomed. 28 (5): 361-365.

18. Kusuma H (2011) Universitas Indonesia Hubungan Antara Depresi Dan Dukungan Keluarga Dengan Kualitas Hidup Pasien Hiv / Aids Yang Menjalani Perawatan. Universitas Indonesia. 
19. House JS (1981) Work stress and social support. AddisonWesley Pub. Co., Reading, Mass..

20. Zung WWK (1971) A rating instrument for anxiety disorders. Psychosomatics 12 (6): 371-379.

21. Gerontoukou E-I, Michaelidoy S, Rekleiti M, Saridi M, Souliotis K (2015) Investigation of anxiety and depression in patients with chronic diseases. Heal. Psychol. Res. 3 (2): 2123.

22. Gerogianni SK, Babatsikou FP (2014) Psychological aspects in chronic renal failure. Heal. Sci. J. 8 (2): 205, 2014.

23. Theofilou P (2011) Depression and anxiety in patients with chronic renal failure: the effect of sociodemographic characteristics. Int. J. Nephrol. 2011: 514070.

24. Dantas RAS, Pelegrino VM, Garbin LM (2007) Avaliação do apoio social e sua relação com variáveis sociodemográficas de pacientes com insuficiência cardíaca em seguimento ambulatorial. Cienc Cuid Saúde 6 (4): 456-462.

25. Naing MM, Nanthamongkolchai S, Munsawaengsub C (2010) Quality of life of the elderly people in einme township irrawaddy division, Myanmar. Asia J Public Heal. $1(2): 4-10$.

26. Al Kahfi R, Rahman S, Palimbo A, Sari NN (2017) The Influence Of Family Support To Patients'anxiety Of Chronic Renal Failure Withexperience Of Hemodialysis At The Hemodialysis Unit Of Ulin Hospital Banjarmasin BT - 2nd Sari Mulia International Conference on Health and Sciences 2017 (SMICHS 2017) One Health to Address the Problem of Tropical Infectious Diseases in Indonesia.

27. De Brito TRP, Pavarini SCI. The relationship between social support and functional capacity in elderly persons with cognitive alterations. Revista Latino-Americana de Enfermagem 20: 677-684.

28. Dziubek W et al. (2016) The level of anxiety and depression in dialysis patients undertaking regular physical exercise training - a preliminary study. Kidney Blood Press. Res. 41 (1): 86-98.

29. Terra FdeS, Costa AMDD, De Figueiredo ET, De Morais AM, Costa MD, Costa RD (2010) Adesão ao tratamento farmacológico de uso diário de pacientes renais crônicos submetidos à hemodiáliseAdhesion of chronic renal hemodialysis patients to daily pharmacologic treatment. Rev. Soc. Bras. Clín. Méd. 8 (2): 1-8.

30. Gregoleti V, Scortegagna SA (2017) The zulliger-CS in elderly on hemodialysis and the relationship between external variables. Paidéia (Ribeirão Preto) 27: 43-50.

31. Kurella M et al. (2005) Chronic kidney disease and cognitive impairment in the elderly: The health, aging, and body composition study. J. Am. Soc. Nephrol. 16 (7): 21272133.
32. Abdel-Rahman EM, Turgut F, Turkmen K, Balogun RA (2011) Falls in elderly hemodialysis patients. QJM An Int. J. Med. 104 (10): 829-838.

33. de JV, Sandri A, Schmitz J (2011) Trajetória da família de portadores de insuficiência renal crônica: desafios e a emergência familiar. Nurs. (São Paulo) 13 (154): 138-143. 